MIECZYSEAW WRZOSEK (Warszawa)

\title{
Z DZIEJÓW RADY GŁÓWNEJ OPIEKUŃCZEJ W GENERALNEJ GUBERNI (1939-1945) ${ }^{1}$
}

W okresie poprzedzającym wybuch drugiej wojny światowej działalnością dotyczącą wspierania osób potrzebujących materialnej pomocy zajmo-

1 Niniejszy artykuł został oparty na kanwie ustaleń faktograficznych, dokonanych przez autora podczas prac związanych z porządkowaniem akt Rady Głównej Opiekuńczej (RGO) w tym czasie, gdy był etatowym pracownikiem Archiwum Akt Nowych w Warszawie. W porządkowaniu tych akt uczestniczyłem jako współpracownik magistra Adama Niesiołowskiego w okresie od 2 listopada 1952 do 23 lutego 1953 r., a następnie jako samodzielny pracownik do 16 lipca tegoż roku. W ciągu dwóch następnych tygodni przygotowałem wstęp do inwentarza, co oznaczało, że w dniu 31 lipca 1953 r. nastąpiło zakończenie moich czynności związanych z uporządkowaniem zespołu akt tak ważnego dla okupacyjnego okresu dziejów narodu polskiego. Dobitnym śladem moich prac nad zespołem akt RGO są tytuły, które zostały przeze mnie sformułowane i zachowały się do dziś na poszczególnych teczkach akt, czyli jednostkach archiwalnych. Wypada tu ponadto zaznaczyć, ze prace związane $\mathrm{z}$ porządkowaniem zespołu akt RGO podejmowałem w sytuacji uwarunkowanej drastycznym naporem czasowym, co wynikało z ówczesnego systemu nacechowanego podejmowaniem tak zwanych „zobowiązań wyścigu pracy”. Był więc ktoś, kto podją takie zobowiązanie bez mojej wiedzy, a ja musiałem temu zobowiązaniu sprostać. Cel ten osiągnąłem natomiast $w$ ten sposób, że jako jednostki potraktowałem wiązki zawierające pod jedna sygnatura po dwanaście miesięcznych sprawozdań powiatowych. Dowiedziałem się po latach, że wyniki prac magistra Niesiołowskiego oraz moje nad zespołem akt RGO zostały potraktowane jako „etap segregacji porządkowanych akt”. Został zatem zbagatelizowany nasz trud związany z główną fazą porządkowania dokumentów RGO, a wznowione prace porządkowe zostały skoncentrowane na rozwiązywaniu paczek zawierających miesięczne sprawozdania. W ten sposób zwiększyła się ogólna ilość jednostek inwentaryzowanego niby to ponownie zespołu akt RGO. Przy okazji zawieruszył się jakoś opracowany przeze mnie wstęp do inwentarza akt RGO, ale jeden jego egzemplarz zachował się szczęśliwie $\mathrm{w}$ moich osobistych papierach. Okoliczności związane z losami zespołu akt RGO zostały tu zamieszczone celowo, ponieważ chodziło o wyjaśnienie, dlaczego autor niniejszego artykułu tak długo zwlekał $z$ wykorzystaniem zebranych wówczas przekazów materiałowych dotyczących działalności RGO. Wypada również zaznaczyć, ze między tymi ustaleniami, jakich dokonał, a rozważaniami zawartymi w monografii profesora Bogdaria Krolla (patrz: B. Kroll, Rada Gtówna Opiekuńcza, Warszawa 1985) zachodza dość istotne różnice. Dalszą prezentację dziejów RGO podejmą przyszli badacze. 
wało się Ministerstwo Opieki Społecznej. Resort ten spełniał zresztą nie tylko zadania związane $\mathrm{z}$ tak zwaną opieką obowiązkową, lecz patronował także zabiegom podejmowanym $\mathrm{w}$ ramach opieki określanej jako pomoc dobrowolna.

Wypada zresztą już tu na wstępie zaznaczyć, że opieka dobrowolna miała bardzo poważne rozmiary, ponieważ wsparcie obowiązkowe nie mogło sprostać tym potrzebom, które utrzymywały się pomimo coraz pomyślniejszego rozwoju ekonomicznego Drugiej Rzeczypospolitej. Jesienią 1939 r. do spotęgowania potrzeb opiekuńczych przyczynił się walnie wybuch drugiej wojny światowej. Działaniom zbrojnym towarzyszyły dotkliwe zniszczenia wielu polskich miast oraz osiedli wiejskich, a ich mieszkańcy utracili swoje mienie i warsztaty pracy. Istotną rolę odgrywało również to, że zaczął następować szybki wzrost cen żywności, odzieży i opału, a zarobki zatrudnianych osób utrzymywały się w zasadzie na dotychczasowym poziomie.

W niniejszym artykule zostaną jednak poruszone tylko te sprawy, które dotyczyły obszaru objętego działalnością Rady Głównej Opiekuńczej (RGO). Będą więc podejmowane rozważania związane $z$ centralną i południową częścią terytoriów zniewolonego państwa polskiego, na których 26 października 1939 r. pojawił się nowy twór administracyjny i zaczął funkcjonować jako General Gouvernement (Generalna Gubernia), czyli z tymi obszarami polskimi, które znalazły się pod zarządem doktora Hansa Franka. Należy ponadto zaznaczyć, że okoliczności towarzyszące działaniom, w których odgrywał czołową rolę, przyczyniły się także do spotęgowania życiowych trudności mieszkańców. Zadecydowało o tym mianowicie przybycie na teren Generalnej Guberni wielkiej liczby przesiedleńców wypędzonych przez władze niemieckie $z$ tak zwanych obszarów wcielonych do Rzeszy i zmuszonych do pozostawienia tam swego mienia. Uzewnętrznił się ponadto napływ uchodźców z obszarów wschodnich, zagarniętych przez sowiecką Rosję na podstawie postanowień wynikających $\mathrm{z}$ traktatu Ribbentrop-Mołotow, zawartego w Moskwie 23 sierpnia 1939 r., zmodyfikowanego zaś częściowo $\mathrm{w}$ toku dodatkowych pertraktacji niemiecko-sowieckich, przeprowadzonych tam w dniach 27 i 28 września tegoż roku ${ }^{2}$.

O powadze sytuacji w istotny sposób decydowało również to, że ofiarą wydarzeń wojennych padła wielka liczba dzieci, kobiet i starców, a więc osób niezdolnych do samodzielnej egzystencji. Dodatkowo zaś przymusowy

2 M. Wrzosek, Zaczatki niemieckiego systemu okupacyjnego na terytoriach polskich opanowanych przez wojska niemieckie jesienia 1939 r., "Studia Podlaskie”, tom VI, Białystok 1996, s. 47, 53 . 
werbunek Polaków wywożonych do pracy na obszarach Rzeszy zataczał coraz szersze kręgi i często nie pomijał jedynych żywicieli rodzin. Powiększała się więc szybko liczba osób potrzebujących materialnego wsparcia. W takich oto okolicznościach akcję opiekuńczą zaczęły podejmować istniejące już samorządy miast oraz osiedli wiejskich, a także organizowane doraźnie komitety pomocy obywatelskiej i komitety samopomocy społecznej. W swej działalności opiekuńczej organizacje te wzorowały się na poczynaniach Stołecznego Komitetu Samopomocy Społecznej, a także na działalności Polskiego Czerwonego Krzyża. W roli koordynatora tych wszystkich wysiłków już niebawem miała wystąpić jednak $\mathrm{RGO}^{3}$.

W tym czasie, gdy poważni członkowie społeczności polskiej rozważali zamysły dotyczące utworzenia instytucji centralnej, powołanej do prowadzenia akcji opiekuńczej, to znaczy w październiku 1939 r., pojawił się w Warszawie Weiss von Ulogg, który występował jako osobnik cieszący się rzekomo dużym zaufaniem premiera Prus, to znaczy marszałka Hermanna Göringa ${ }^{4}$. Pobyt von Ulogga w Warszawie trwał kilka dni i doszło wówczas do jego spotkania z Adamem Ronikierem, który w okresie pierwszej wojny światowej stał na czele charytatywnej organizacji polskiej, występującej jako Rada Główna Opiekuńcza. Misja berlińskiego przybysza miała jednak jakiś zagadkowy charakter. Usiłował on przekonać Ronikiera, że Polacy powinni szukać oparcia ze strony Göringa, bo tylko w taki sposób mogą osiągnąć tyle, że na tych obszarach polskich, które znalazły się pod niemieckim panowaniem, nie dojdzie do „bezwzględnych rządów silnej ręki”. W związku z owymi sugestiami hrabia Ronikier nawiązał kontakt $\mathrm{z}$ Norbertem Barlickim, Bolesławem Lutomskim, a także z profesorem Romanem Rybarskim. W porozumieniu z tymi osobami sporządził rzeczową notatkę, która miała być przedstawiona przez von Ulogga samemu Göringowi. Zawierała ona postulaty Polaków, w których chodziło o powstrzymanie procesu narastającej nędzy. W związku z tym zostały uwypuklone zwłaszcza takie sprawy, jak: powołanie instytucji organizującej pomoc społeczną, założenie banku emi-

3 M. Wrzosek, Wstęp do inwentarza akt zespotu RGO drugiej okupacji, Warszawa 1953. Pierwszy i drugi egzemplarz tego opracowania w dniu 31 lipca 1953 r. został przekazany dyrektorowi Archiwum Akt Nowych, to znaczy doktorowi Zygmuntowi Kolankowskiemu. Trzeci egzemplarz maszynopisu tego opracowania, egzemplarz zapewne ostatni, jaki się zachował, znajduje się w posiadaniu autora niniejszego artykułu.

4 Bogdan Kroll podaje, że Göring był prezesem Rady Ministrów Rzeszy. Jest to nieścisłość, ponieważ na czele rządu Rzeszy stał kanclerz Adolf Hitler, który po śmierci prezydenta Pawła von Hindenburga był jednocześnie również głową całego państwa niemieckiego. Zob. B. Kroll, op. cit., s. 51. 
syjnego oraz utworzenie straży obywatelskiej mającej na celu utrzymanie porządku i zapobieganie anarchii ${ }^{5}$.

W odniesieniu do wzmianki o tych sugestiach nasuwa się przypuszczenie, że berliński rozmówca Ronikiera był uczestnikiem swoistej akcji sondażowej. Taka akcja, jak to wynika z niektórych polskich opracowań historycznych, miała wynikać z przejściowego zamysłu dotyczącego utworzenia jakiegoś szczątkowego państwa polskiego (Reststaatu) i polegała, między innymi, na poszukiwaniu jakichś wybitniejszych przedstawicieli społeczności polskiej, którzy mieliby odwagę stanąć na czele polskiego, kadłubowego tworu państwowego ${ }^{6}$.

Problem szczątkowego państwa polskiego wyłonił się na początku drugiej dekady września 1939 r. Został poruszony, między innymi, podczas narady sztabowej, która odbywała się 12 września w Jełowej na Śląsku. $\mathrm{Z}$ dostępnych przekazów materiałowych wynika jakoby Hitler skłaniał się ku realizacji tego pomysłu?

W listopadzie 1939 r. do Warszawy przybyła delegacja Amerykańskiego Czerwonego Krzyża, a w roli jej przewodniczącego występował Columbia P. Murray. W skład tej delegacji wchodził ponadto przedstawiciel Polish Food Commission (Polskiej Komisji Pomocy Żywnościowej), określanej powszechnie jako Komisja Hoovera ${ }^{8}$. Przedstawicielem tej komisji był Mac Donald. Stosując się do poleceń Hoovera, nawiązał on w Warszawie kontakt z Adamem Ronikierem, którego wcześniejsza działalność opiekuńcza nie została zapomniana przez Amerykanów. Uwaga Mac Donalda miała się natomiast koncentrować na omówieniu spraw związanych z potrzebami społeczności polskiej oraz na ustaleniu możliwości i form deklarowanej pomocy. Obaj rozmówcy (Mac Donald i Ronikier) doszli do wniosku, że powinna powstać organizacja złożona wyłącznie z Polaków. Pełnomocnik Hoovera eksponował także konieczność postawienia na czele takiej organizacji osoby odpowiedzialnej za całokształt akcji opiekuńczej, a jednocześnie zastrzegał prawo do kontroli tej działalności przez przedstawicieli fundatorów amery-

5 B. Kroll, op. cit., s. 244.

6 Szerzej o tych sprawach zwłaszcza Czesław Madajczyk, Generalna Gubernia w planach hitlerowskich, Warszawa 1961, s. 11-16; por. także: M. Wrzosek, Zaczatki niemieckiego systemu..., s. 52-61. s. 556

7 A. Ballock, Hitler. Eine Studie über Tyrannei, Droste Verlag, Dïsseldorff 1957,

8 Chodzi konkretnie o Herberta Clarka Hoovera, który był prezydentem Stanów Zjednoczonych w latach 1929-1933, a po pierwszej i po drugiej wojnie światowej kierował organizacją pomocy amerykańskiej dla krajów europejskich. 
kańskiej pomocy ${ }^{9}$. W tych ustaleniach chodziło głównie o jakieś możliwe do osiągnięcia ograniczenie ingerencji niemieckich władz okupacyjnych.

Amerykańska delegacja nie ograniczyła swej akcji do rozmów z Ronikierem. Wiadomo mianowicie, że przewodniczący owej delegacji, to znaczy Murray, nawiązał kontakt ze Stanisławem Arctem, który był w Ameryce znany również bardzo dobrze, ponieważ przed wybuchem drugiej wojny światowej występował jako prezes Polsko-Amerykańskiej Izby Handlowej, a jednocześnie jako wiceprezes Towarzystwa Polsko-Amerykańskiego. Podczas spotkania Murray zaproponował Arctowi objęcie kierownictwa nad organizacją, której zadanie miało polegać na przyjmowaniu i podziale amerykańskich darów ${ }^{10}$.

Po opuszczeniu Warszawy Mac Donald udał się do Berlina, a hrabia Ronikier wziął udział w plenarnym spotkaniu czołowych działaczy dotychczasowej akcji opiekuńczej. Chodzi tu o takich, między innymi, działaczy SKSS, jak: Stanisław Arct, Marian Borzęcki, Henryk Drozdowski, Stefan Dziewulski, Jan Stanisław Jankowski, Antoni Kaczorowski, Julian Kulski, Władysław Lewandowicz, Zdzisław Lubomirski, Janusz Machnicki, Mieczysław Niedziałkowski, Maciej Rataj, Janusz Radziwiłł, Witold Staniszkis, Jan Starczewski, Jan Strzelecki, Artur Śliwiński, Leopold Vieweger i Andrzej Wierzbicki. Do tej narady doszło 19 listopada 1939 r. ${ }^{11}$

Wyniki rozmów, jakie zostały przeprowadzone z przybyszami zza Oceanu, referował Śliwiński. Podczas swojego wystąpienia przedstawił amerykańskie założenia organizacyjne oraz propozycje personalne. W toku dyskusji Rataj i Staniszkis kwestionowali potrzebę tworzenia nowej organizacji opiekuńczej, skoro swoją działalność rozwija już SKSS, zaś Lewandowicz opowiadał się za dążeniem do uniezależnienia tegoż komitetu i uzasadniał potrzebę jego przekazania pod patronat Międzynarodowego Czerwonego Krzyża.

W związku z tą wypowiedzią Ronikier stwierdził, że jest to postulat nierealny. Takie samo stanowisko zajął Arct. Ponad to powołał się w tej sprawie na informacje uzyskane w ambasadzie amerykańskiej, dodając, że organizacja rozdzielająca dary amerykańskie musi być kontrolowana przez władze niemieckie, które nie wyrażą zgody na jakiekolwiek powiązania organiza-

9 M. Wrzosek, Wstęp do..., s. 1.

10 B. Kroll, op. cit., s. 52; por. także: H. Drozdowski, Stołeczny Komitet Samopomocy Spotecznej (SKSS) w okresie II wojny światowej, t. II, Instytut Historii Polskiej Akademii Nauk, A 6/57, s. 65 (przytoczone za ustaleniami Bogdana Krolla).

11 B. Kroll, op. cit., s. 52. 
cyjne między SKSS a Międzynarodowym Czerwonym Krzyżem. Jednocześnie Arct zaznaczył, że nie podejmie się roli kierownika w takiej organizacji, która będzie przez Niemców kontrolowana. Gotowość objęcia kierownictwa nad organizacją podejmującą działalność opiekuńczą nie tylko w Warszawie, lecz także na obszarze całej Generalnej Guberni zadeklarował natomiast Ronikier. Zapowiedział ponadto nawiązanie do tradycji związanych z działalnością Rady Głównej Opiekuńczej podczas pierwszej wojny światowej i wysunął przypuszczenie, że może liczyć na zatwierdzenie swojej kandydatury przez władze niemieckie.

Przeciw kandydaturze Ronikiera występował Radziwiłł, dowodząc, że dotychczasową swoją działalnością uzewnętrznił brak dostatecznej gospodarności. Odpowiednimi kwalifikacjami, zdaniem Radziwiłła, dysponował Wierzbicki, znany w kraju jako współzałożyciel oraz prezes Centralnego Związku Polskiego Przemysłu, Górnictwa, Handlu i Finansów. Prezes tego związku, czyli tak zwanego Lewiatana, nie wyraził jednak na to swojej zgody. W ten sposób umocniła się szansa kandydatury Ronikiera, ale został on zobowiązany do porozumiewania się $\mathrm{w}$ sprawach organizacyjnych $\mathrm{z}$ krakowskim środowiskiem polskim, zwłaszcza zaś z arcybiskupem Adamem Księciem Sapiehą.

W tym czasie, gdy odbywały się narady czołowych działaczy warszawskich, Mac Donald podejmował już pertraktacje z przedstawicielami władz niemieckich, głównie z Göringiem. W toku tych rozmów dysponował kopią notatki, którą von Ulogg miał dostarczyć Göringowi. W sprawach związanych z losem oryginału oraz tej kopii, którą otrzymał działacz amerykański, nie zachowały się żadne informacje. Doszło natomiast niebawem do powołania Banku Emisyjnego w Krakowie i zaznaczał się postęp w kwestiach dotyczących utworzenia insty tucji koordynu jącej opiekę społeczną. Z niemieckich przekazów źródłowych wynika mianowicie, że to zainteresowanie okazywał zwłaszcza przedstawiciel Narodowo-Socjalistycznej Opieki Społecznej (Nationlsozialistische Volkswohlfahrt (NSV)) przy Urzędzie Generalnego Gubernatora, to znaczy SS-Standartenführer Wilhelm von Janowski. W dniu 10 listopada 1939 r. poinformował on generalnego gubernatora o amerykańskich propozycjach. Generalny gubernator Frank stwierdził wówczas, że nie można dopuścić do bezpośrednich kontaktów polsko-amerykańskich, wyraził jednak zgodę na udzielanie materialnej pomocy mieszkańcom Generalnej Guberni, ale za pośrednictwem odpowiednio kontrolowanej organizacji ${ }^{12}$. 
Wyraźny sygnał o zainteresowaniu, jakie strona niemiecka zaczynała okazywać akcji związanej z pomocą społeczną, uzewnętrznił się jednak dopiero 1 grudnia 1939 r. W tym właśnie dniu Urząd Generalnego Gubernatora zwrócił się do byłego polskiego Ministerstwa Opieki Społecznej, zachowującego jeszcze szczątkowe fragmenty poprzednich struktur organizacyjnych i wezwał do swojej krakowskiej siedziby urzędnika najwyższego ranga spośród tych, którzy nie opuścili kraju. W związku z tym wezwaniem stawił się w Krakowie Stefan Łopatto, który przed wojną był naczelnikiem w Wydziale Nadzoru i Polityki Społecznej. Do gmachu zajmowanego przez Urząd Generalnego Gubernatora udał się on w towarzystwie kilku członków krakowskich organizacji społecznych i przedstawicieli Polskiego Czerwonego Krzyża. Jako główny rozmówca tych osób wystąpił natomiast doktor Fritz Arlt, który był szefem Wydziału Zdrowia i Opieki Społecznej w Urzędzie Generalnego Gubernatora ${ }^{13}$.

Przedstawiciel władz niemieckich oświadczył zebranym przedstawicielom strony polskiej, że musi powstać centralna instytucja pomyślana jako organizator społecznej działalności opiekuńczej. Doktor Arlt przewidywał, że rolę takiej instytucji zacznie odgrywać Polski Czerwony Krzyż i napomknął, że centralny organ tej właśnie instytucji zostanie przeniesiony z Warszawy do Krakowa. Zwrócił się ponadto o przedstawienie projektu wewnętrznej organizacji tej centralnej instytucji opartej na strukturach PCK. Postulowany projekt był szkicowany w krakowskim oddziale PCK, a w czynnościach związanych z jego przygotowaniem uczestniczył także naczelnik Łopatto. W toku tych czynności krakowscy społecznicy doszli do wniosku, że organizacją $\mathrm{w}$ sprawach opiekuńczych najbardziej odpowiednią będzie jednak Zarząd Główny PCK. Uznali ponadto, że w tym właśnie organie nie sa potrzebne żadne istotne zmiany. Postanowiono zatem, że w dalszych czynnościach, mających na celu uruchomienie działalności opiekuńczej, winna uczestniczyć hrabina Maria Tarnowska jako urzędu jący wiceprezes Zarządu Głównego PCK ${ }^{14}$.

Zaproszenie hrabiny Tarnowskiej do udziału we wstępnych pracach organizacyjnych było uzgodnione $z$ zainteresowanymi tą sprawą czynnikami niemieckimi. Zostało przez hrabinę przyjęte i pani wiceprezes PCK udała się również do Krakowa. Uczyniła to niezwłocznie i przywiozła egzemplarz projektu przygotowanego w Warszawie, a ponadto zaznaczyła $z$ naciskiem,

13 M. Wrzosek, Wstęp do..., s. 1.

14 Ibidem. 
że hrabia Ronikier pertraktował z przedstawicielami charytatywnych organizacji amerykańskich i dysponu je gotowym projektem struktur wewnętrznych centralnej organizacji opiekuńczej. Oświadczenie to wzbudziło żywe zainteresowanie doktora Arlta i skłoniło go do zaproszenia hrabiego Ronikiera na konferencję w Krakowie. Zaproszenie to, pojmowane w istocie jako wezwanie, zostało jednak przyjęte. Hrabia Ronikier 13 grudnia 1939 r. przybył do Krakowa i rozpoczęło się szczegółowe uzgadnianie założeń dotyczących zasięgu oraz zasad, zgodnie $\mathrm{z}$ którymi miała funkcjonować działalność opiekuńcza na obszarze Generalnej Guberni ${ }^{15}$.

W rozmowach $\mathrm{z}$ doktorem Arltem, oprócz hrabiego Ronikiera, uczestniczyło jeszcze kilka osób, w gronie których znajdowała się hrabina Tarnowska. Był tam również naczelnik Łopatto. Po stronie polskiej największą aktywność okazywał hrabia Ronikier, który zaprezentował projekt uzgodniony najpierw z Mac Donaldem, a potem dopracowywany szczegółowo w toku narad odbywających się w środowisku warszawskim. Był wzorowany na Radzie Głównej Opiekuńczej okresu pierwszej wojny światowej i z wywodów Ronikiera wynika, że taką samą nazwę zamierza nadać tej centralnej organizacji opiekuńczej, jaką miano powołać w nowych okolicznościach. Dr Arlt przy jął projekt zaprezentowany przez Ronikiera, zaznaczając jednak z naciskiem, że to, co czyni, nie jest wyrazem akceptacji, lecz powinno być traktowane jako zabieg wstępny, ułatwiający rozpatrzenie całej sprawy w Urzędzie Generalnego Gubernatora ${ }^{16}$.

Kolejne spotkanie przedstawicieli strony polskiej i funkcjonariuszy Urzędu Generalnego Gubernatora nastąpiło z inicjatywy strony niemieckiej, a doszło do niego dopiero 22 stycznia 1940 r. Stronę polską, oprócz hrabiego Ronikiera i naczelnika Łopatty, reprezentował tym razem także były austriacki minister doktor Juliusz Twardowski, a rozmówcami wymienionych tu Polaków, obok Arlta byli: doktor Westphal (reprezentował wyższego dowódcę SS i policji, to znaczy SS-Obergruppenführera Friedricha Kriigera) oraz doktor N. Sanne (pełnomocnik Niemieckiego Czerwonego Krzyża w Ge-

15 Szerzej o tych sprawach Bogdan Kroll, op. cit., s. 55-57; wymieniony tu autor zamieścił ponadto w swojej cennej monografii dość obszerną wzmiankę o zabiegach podejmowanych przez wspomnianego juz wcześniej von Janowskiego, który porozumiewał się z berlińskimi czynnikami Narodowo-Socjalistycznej Niemieckiej Partii Robotniczej (NSDAP) i dążył do ukształtowania opieki społecznej na obszarze Generalnej Guberni zgodnie z założeniami obowiązującymi w strukturach NSV i działającej według zasad, na których była oparta „niemiecka pomoc zimowa”. W zabiegach tych von Janowski został jednak powstrzymany na polecenie generalnego gubernatora.

16 B. Kroll, op. cit., s. 58. 
neralnej Guberni) i Friedrich Siebert (kierownik Wydziału Spraw Wewnętrznych w Urzędzie Generalnego Gubernatora). Na żądanie Sannego przedstawiciele strony polskiej opracowali swoistą deklarację, która prezentowała się $\mathrm{w}$ istocie jak projekt statutu polskiej centralnej organizacji opiekuńczej. Dokument ten znalazł aprobatę doktora Sanne i takie samo stanowisko zajęli także Arlt oraz Siebert. W związku z tym hrabia Ronikier uznał, że jest to równoznaczne $z$ ostateczną akceptacją jego poczynań organizacyjnych i udał się na dworzec kolejowy z zamiarem odjazdu do Warszawy. Ku swojemu zaskoczeniu został jednak zatrzymany przez niemiecką policję i musiał wrócić do Urzędu Generalnego Gubernatora. Okazało się tam, że projekt statutu nie spotkał się z aprobatą Krïgera, bo nie godził się on na 24-osobowy skład rady mającej występować jako naczelna instancja powoływanej organizacji opiekuńczej. Wykluczał ponadto zamiar objęcia opieką społeczną ludności żydowskiego pochodzenia. Hrabia Ronikier występował jednak w obronie swojego projektu i czynił to dość odważnie. Do ostatecznego rozstrzygnięcia tych spornych kwestii doprowadziła dopiero specjalna decyzja generalnego gubernatora Franka, który wyraził zgodę na powołanie rady pomyślanej jako zwierzchnia instancja organizacji opiekuńczej, ale miała stanowić gremium ograniczone w swoim składzie do liczby 5-6 osób. Gubernator Frank wyraził również zgodę na to, że projektowana instytucja będzie występować jako Rada Główna Opiekuńcza (RGO) ${ }^{17}$.

Po wnikliwej analizie projektu złożonego przez hrabiego Ronikiera, centralny organ władz Generalnej Guberni wniósł do tekstu tego dokumentu znaczne uzupełnienia oraz uściślenia, uwzględniające niemiecki punkt widzenia na sprawy związane $z$ działalnością opiekuńczą. W dniu 14 lutego 1940 r. taki zmodyfikowany statut polskiej organizacji opiekuńczej został przekazany wszystkim starostom (landratom). Tymczasem okazało się, że wielu $z$ nich, działając $z$ własnej inicjatywy, zaczęło powoływać lokalne rady powiatowe. Postępowanie takie spowodowało sporo zamieszania, które zaczęło ustępować dopiero wówczas, gdy zapadło stanowcze postanowienie, że takie lokalne organizacje opiekuńcze powinien powoływać tylko centralny organ opiekuńczy, to znaczy RGO, ponieważ był odpowiedzialny za całokształt spraw związanych $\mathrm{z}$ działalnością opiekuńczą ${ }^{18}$.

Dalsza działalność opiekuńcza odbywała się zasadniczo zgodnie z zaaprobowanymi ustaleniami statutowych powołanej organizacji, ale w praktyce wyłaniały się różnorodne przeszkody i trudności, które zmuszały tę

\footnotetext{
17 Ibidem.

18 M. Wrzosek, Wstęp do..., s. 2.
} 
polską organizację chary tatywną do podejmowania działań niezwykle ostrożnych i elastycznych zarazem. Statut RGO był ujęty w sposób bardzo lakoniczny i zawierał tylko ramowe ustalenia ${ }^{19}$. W związku z tym naczelna instancja organizacji, czyli RGO pojmowana tu w ścisłym znaczeniu tych określeń, uznała konieczność opracowania dokumentu omawiającego szerzej zarówno własne kompetencje, jak też zasady współdziałania $z$ władzami niemieckimi oraz różnymi polskimi instytucjami i przedsiębiorstwami o charakterze ekonomicznym. Wykonaniem tego trudnego zadania został obarczony naczelnik Łopatto ${ }^{20}$.

Z wynikami zabiegów mających na celu powołanie polskiej organizacji opiekuńczej hrabia Ronikier zapoznał następnie arcybiskupa księcia Sapiehę, który okazywał tym sprawom swoje żywe zainteresowanie. Podczas spotkania $\mathrm{z}$ tym wybitnym arcypasterzem Kościoła katolickiego uzyskał charakterystykę osób przewidzianych do ewentualnego zaangażowania w działalność RGO, a wywodzących się ze środowiska krakowskiego. Jako przedstawiciela duchowieństwa arcybiskup Sapieha wymienił osobę organizatora Sodalicji Mariańskich, a zarazem katolickiego publicysty, to znaczy jezuity ojca Romualda Moskały, a także dziekana Wydziału Prawa na Uniwersytecie Jagiellońskim, czyli profesora Władysława Woltera ${ }^{21}$.

W dniu 22 lutego 1940 r. odbyło się spotkanie osób, które miały być powołane $\mathrm{w}$ skład centralnego organu RGO. Było to w istocie pierwsze, co prawda jeszcze nieformalne, posiedzenie tego organu, który się właśnie wówczas ukonstytuował. Odbywało się ono w Krakowie, w pałacu wynajętym od Franciszka Pusłowskiego przy ulicy Andrzeja Potockiego $10^{22}$. Na stanowisko prezesa został wybrany książę Janusz Radziwiłł, a hrabia Adam Ronikier został niby wiceprezesem, ale był upoważniony do tego, że będzie Radziwiłła ustawicznie zastępował, reprezentując Radę także na zewnątrz i prowadząc pertraktacje zarówno z funkcjonariuszami władz niemieckich, jak też z przedstawicielami zagranicznych misji dobroczynnych ${ }^{23}$. W tym wstępnym posiedzeniu, oprócz wymienionych już osób, uczestniczyli ponadto: Stefan Łopatto (przewidziany na stanowisko dyrektora w biurze wykonawczym RGO), Wojciech Baranowski (miał objąć stanowisko generalnego sekretarza), a także Henryk Potocki, Antoni Plater i Wanda Bobkowska

19 Bardziej szczegółowa charakterystyka tego dokumentu nastąpi nieco później.

M. Wrzosek, Wstęp do..., s. 2.

B. Kroll, op. cit., s. 60.

22

Ibidem, s. 59.

23 Ibidem. 
(działaczka PCK) ${ }^{24}$. Do współpracy z ludnością pochodzenia żydowskiego był wytypowany Marek Bieberstein ${ }^{25}$. Te wstępne czynności były dostosowywane do założeń wynikających ze statutu opracowanego przez naczelnika Łopattę przy częściowym udziale hrabiego Ronikiera oraz Juliusza Twardowskiego.

Dokument ten określał zasady działania RGO. Uwzględniał mianowicie kompetencje Rady pojmowanej jako naczelny organ całej organizacji i mającej w swoim składzie osobowym pięciu Polaków i jednego Żyda, a także określał prerogatywy Rady Nadzorczej, złożonej z 23 Polaków oraz dwóch Żydów. Przewidywał ponadto, że działalność centralnych członów organizacji będzie się opierała na współpracy z przedstawicielem Niemieckiego Czerwonego Krzyża (NCK) w Generalnej Guberni oraz na porozumieniu z kierownikiem Wydziału Spraw Ludności i Opieki w Urzędzie Generalnego Gubernatora. Centralnemu członowi RGO miała przysługiwać możliwość reprezentowania polskich spraw opiekuńczych wobec zagranicy, a także prawo podziału środków napływa jących jako zagraniczna pomoc za pośrednictwem NCK i gromadzonych w kraju w wyniku dobrowolnej zbiórki. Rada miała ponadto roztaczać opiekę nad osobami przesiedlanymi $z$ terenów wcielonych do Rzeszy i nad uchodźcami ze wschodnich obszarów Rzeczypospolitej. W związku z realizacją zadań charytatywnych, Radzie miały podlegać komitety powiatowe, złożone $\mathrm{z}$ sześciu Polaków, w gronie których winien się znaleźć przewodniczący każdego powiatowego związku opieki i kierownik powiatowego oddziału PCK. Skład osobowy powiatowych komitetów opiekuńczych był uzależniony od aprobaty niemieckiego starosty, to znaczy landrata ${ }^{26}$.

W połowie marca $1940 \mathrm{r}$. władze niemieckie zakwestionowały dotychczasowe ustalenia statutowe oraz załączone do nich uściślenia regulaminowe i odmówiły uznania tych dokumentów, jednocześnie przedstawiły dokument zawierający sformułowania zapowiadające wyraźne pomniejszenie kompetencji RGO. Niemieckim czynnikom okupacyjnym chodziło zwłaszcza o daleko idącą redukcję składu osobowego Rady Nadzorczej, czyli o pozbawienie RGO poważniejszego oparcia w społeczeństwie polskim. Władze niemieckie dążyły nawet do utrudnienia szerszego oraz swobodniejszego współdziałania centralnych organów RGO z terenowymi ogniwami tej opiekuńczej organizacji. Nawiązanie kontaktów RGO z zagranicznymi organizacjami

\footnotetext{
24 B. Kroll, op. cit., s. 59.

25 M. Wrzosek, Wstęp do.., s. 2.

26 B. Kroll, op. cit., s. 62.
} 
charytatywnymi chciały wręcz uniemożliwić. Zależało im na daleko idącym uzależnieniu od organów niemieckiego systemu okupacyjnego. Chciały to osiągnąć poprzez wprowadzenie języka niemieckiego do obrad, protokołów i korespondencji RGO, a także dzięki ulokowaniu w siedzibie RGO swojego przedstawiciela, wydelegowanego przez Wydział Spraw Ludności i Opieki z Urzędu Generalnego Gubernatora na stanowisko w ważnym ogniwie RGO, to znaczy w Referacie Dobrowolnej Opieki Społecznej27.

Temu niebezpiecznemu dokumentowi strona polska przeciwstawiła kilka projektów, w których były brane pod uwagę nie tylko interesy własne, lecz także sprawy związane $\mathrm{z}$ opieką przysługującą ludności żydowskiej. Chodziło ponadto o rozwiązanie problemu pomocy przeznaczonej dla ludności ukraińskiej, co akcentowała również strona niemiecka. W środowisku polskim wyłoniły się wówczas dwie koncepcje. Jedna $z$ nich przewidywała, że do zwierzchniego organu RGO, oprócz Polaków, zostanie powołany jeden przedstawiciel Żydów i jeden reprezentant Ukraińców. Druga koncepcja opierała się na założeniu, że RGO będzie się zajmować wyłącznie pomocą okazywaną Polakom, a jednocześnie podejmą działalność dwie inne organizacje charytatywne, występujące jako Ukraińska Rada Główna i jako Żydowska Samopomoc Społeczna. Ta druga koncepcja zyskała więcej zwolenników. Jej założeniom towarzyszyła propozycja, zgodnie z którą miało dojść do ustanowienia instancji koordynującej całokształt działalności charytatywnej, występującej jako Naczelna Rada Opiekuńcza i mającej w swoim składzie osobowym pięciu Polaków, jednego Żyda oraz jednego Ukraińca. Członkowie organu ukształtowanego na takich zasadach mieli się zbierać na wspólnych posiedzeniach zwoływanych jednak tylko w miarę potrzeb ${ }^{28}$.

Wypada tu zaznaczyć, że obie koncepcje polskie spotkały się z negatywnym stanowiskiem władz niemieckich. Uzewnętrzniła się więc skomplikowana sytuacja, ponieważ na obszar Generalnej Guberni dotarły już pierwsze dostawy darów amerykańskich. Zaczynała się też niemiecka akcja przesiedleńcza, która dotknęła Polaków wydalanych do Generalnej Guberni z obszarów wcielonych do Rzeszy. Ożywiona akcja organizacyjna nasilała się również na prowincji, to znaczy w poszczególnych powiatach Generalnej Guberni. W takich oto warunkach 27 maja 1940 r. doszło do ważnego posiedzenia członków najwyższego organu RGO i w toku obrad tego gremium zapadły decyzje dotyczące wewnętrznej struktury centralnego biura tej organizacji charytatywnej. Centralne biuro RGO rozpoczynało więc swoją dzia-

27 Ibidem; M. Wrzosek, Wstęp do.., s. 2.

28

Ibidem, s. 2. 
łalność, a organ, któremu podlegało, nie dysponował jeszcze ani statutem, ani też regulaminem wewnętrznym. Oba te dokumenty zostały jednak zatwierdzone przez generalnego gubernatora w dwa dni później, to znaczy 29 maja 1940 r. ${ }^{29}$ Naczelny organ RGO nie został jednak o tym powiadomiony, a odpowiednią informację, jak stwierdza Bogdan Kroll, otrzymał dopiero 13 lipca tegoż roku ${ }^{30}$.

Były to dokumenty oparte na kompromisie wymuszonym przez władze niemieckie. Negocjatorom polskim udało się jednak uzyskać pewne ustępstwa. Nie zapadło więc postanowienie, że w skład RGO wejdzie przedstawiciel nacjonalistów ukraińskich i nie doszło do zastosowania obowiązku używania języka niemieckiego jako urzędowego w bieżącej działalności tej organizacji charytatywnej. Dokumenty zawierające przepisy statutowe oraz regulaminowe były natomiast ujęte w sposób nadmiernie zwięzły, określany niekiedy jako ramowy, zapewniały natomiast stronie niemieckiej dogodną ich interpretację i wymagały dodatkowych objaśnień, których zestaw potem stopniowo narastał ${ }^{31}$.

Uregulowane $\mathrm{w}$ ten sposób formalno-prawne podstawy działalności RGO nie doprowadziły jednak do przezwyciężenia wszystkich przeszkód związanych $z$ funkcjonowaniem tej organizacji. Okazało się mianowicie, że doktor Frank nie wyraził zgody na to, żeby prezesem RGO został książę Janusz Radziwiłł. O tym odmownym stanowisku generalnego gubernatora RGO została poinformowana 31 maja 1940 r. i na zwołanym niezwłocznie posiedzeniu podała się do dymisji. Postanowienia tego, pomimo nacisków ze strony niemieckiej, odwołać nie chciała i hrabia Ronikier potwierdził tę decyzję pisemnym oświadczeniem, które wręczył naczelnikowi Arltowi. Jednocześnie napomknął, że do rozwiązania sporu dojdzie w razie powołania Rady w nowym składzie osobowym, jeżeli warszawskie środowisko polskich działaczy społecznych nakłoni księcia Radziwiłła do ustąpienia. Pożądana zgoda księcia, pomimo perswazji Ronikiera i nacisków arcybiskupa Sapiehy, jednak nie nastąpiła. O przezwyciężeniu związanych z tym trudności zadecydował ostatecznie arcybiskup, ponieważ uznawał konieczność rozwinięcia działalności charytatywnej i zalecił Ronikierowi zarówno powrót do RGO, jak też objęcie kierownictwa nad tą organizacją. Na wycofanie złożonej dymisji zdecydowali się ponadto dwaj inni działacze, to znaczy Henryk Kuła-

29 B. Kroll, op. cit., s. 64 .

30 Ibidem, s. 67.

31 Ibidem. 
kowski oraz jezuita ojciec Romuald Moskała. Swoją rezygnację podtrzymała natomiast hrabina MariaTarnowska i Stefan Łopatto ${ }^{32}$.

W lipcu 1940 r. prezes Ronikier skompletował nowy skład RGO. W kierownictwie powoływanej organizacji, oprócz prezesa Adama Ronikiera, znaleźli się tym razem: Janusz Machnicki jako wiceprezes, Henryk Kułakowski (zajął się finansami), jezuita ojciec Romuald Moskała (przystąpił do organizowania pomocy dla potrzebujących), profesor Maksymilian Rutkowski (zaczął odpowiadać za kwestie dotyczące zdrowia) i profesor Władysław Wolter (kierował zagadnieniami organizacyjno-prawnymi). Obowiązki Zygmunta Lasockiego nie zostały natomiast określone w sposób ścisły, a dyrektorem biura został doktor Witold Celichowski ${ }^{33}$.

W takim składzie osobowym Rada funkcjonowała tylko do grudnia 1940 r., ponieważ Rząd Generalnego Gubernatora odmówił zatwierdzenia kandydatury Lasockiego ${ }^{34}$. Miejsce opuszczone przez działacza zakwestionowanego przez władze niemieckie zajął dawny wojewoda poznański Adam Raczyński, który w okresie przedwojennym był także wiceministrem rolnictwa i reform rolnych ${ }^{35}$. Pojawił się ponadto ważny organ, a mianowicie Naczelna Rada Opiekuńcza (NRO), która była rzecznikiem potrzeb trapiących zarówno Polaków, jak też Żydów i Ukraińców, a swoją aktywność uzewnętrzniała zwłaszcza przy podziale darów zagranicznych.

Zasadnicze zadania RGO, pojmowanej tu jako cała organizacja, były określone w czterech pierwszych paragrafach zatwierdzonego statutu. Stwierdzały one, że powołana organizacja ma w Krakowie siedzibę swoich centralnych władz i zespala działalność wszystkich polskich organizacji dobrowolnej opieki społecznej, nie naruszając jednak ich samodzielności, dotychczasowych statutów, ani też stanu majątkowego. Postanowienie to odnosiło się również do Polskiego Czerwonego Krzyża, ale tylko w odniesieniu do prac charytatywnych. Z dalszych uściśleń wynikało natomiast, że zakres właściwych zadań RGO miał obejmować: całokształt potrzeb opiekuńczych, zdobywanie środków przeznaczonych na realizacje tej opieki, rozdzielanie ofiar pieniężnych i darów składanych w naturze, organizowanie i wspieranie zakładów oraz instytucji opieki społecznej, a także podejmowanie współpracy z zagranicznymi organizacjami opieki społecznej, ale za

32 lbidem, s. 67.

33 Ibidem, s. 72; por. także M. Wrzosek, Wstęp do..., s. 2,

34 Bogdan Kroll wzmiankuje, że o tej odmowie zadecydowała jego wcześniejsza dość znaczna aktywność w Stronnictwie Ludowym; przypuszczenie to nie jest bezpodstawne. Patrz: B. Kroll, op. cit., s. 72 .

35 Ibidem, s. 72. 
pośrednictwem pełnomocnika Niemieckiego Czerwonego Krzyża. Wszystkie wymienione zadania RGO miała ograniczać jednak tylko do potrzeb ludności polskiej, to znaczy z pominięciem Ukraińców i Żydów.

W paragrafie pierwszym, a także w kilku następnych fragmentach statutu była wymieniona oficjalna nazwa powoływanej organizacji charytatywnej. W brzmieniu niemieckim określały ja słowa: „Polnischer Hauptausschus". W tłumaczeniu polskim było to równoznaczne z nazwą "Rada Główna Opiekuńcza". Określenie to odnosiło się jednak tylko do centralnego organu powoływanej organizacji, ponieważ istniały także terenowe „rady główne opiekuńcze", ale do tego obiegowego określenia były zobowiązane dodawać nazwę swojej siedziby. Nazwa takiej terenowej organizacji, przykładowo rzecz ujmując, powinna brzmieć więc następująco: Rada Główna Opiekuńcza w Siedlcach, w Sokołowie Podlaskim itp. ${ }^{36}$

Równolegle $z$ pracami dotyczącymi sformułowań statutowych oraz regulaminowych postępowały zabiegi związane $\mathrm{z}$ ukształtowaniem struktur terenowego aparatu opieki społecznej. Na czoło tych zabiegów wysuwał się dobór działaczy i pracowników. Przy rozwiązywaniu tego problemu okazały się pomocne nazwiska społeczników wymienionych w wykazach dostarczanych przez terenowe ogniwa PCK oraz innych organizacji opiekuńczych. RGO, wysuwając kandydatów do zatwierdzenia przez władze niemieckie, kładła nacisk na ich fachowe przygotowanie i zwyczajną uczciwość oraz na zaufanie, jakim cieszyli się w środowiskach polskich. Terenowe organy RGO dysponowały daleko idącą swobodą działania, ale napotykały różnorodne przeszkody wynikające $z$ postawy landratów, którzy przedstawiane im wnioski osobowe zatwierdzali bardzo niechętnie. Proces tego zatwierdzania przebiegał więc wolno i zakończył się dopiero w 1941 r. Podobne trudności wynikały również w związku z powoływaniem rad opiekuńczych szczebla gminnego. Instrukcja dotycząca trybu powoływania tych rad nie doczekała się zatwierdzenia i te najniższe instancje opiekuńcze były kompletowane na podstawie doraźnych uzgodnień z przedstawicielem Urzędu Generalnego Gubernatora. Po przezwyciężeniu tej przeszkody terenowe delegatury mogły rozwinąć działalność, która miała wielkie znaczenie, ponieważ na tej właśnie najszerszej płaszczyźnie działania odbywała się ewidencja osób potrzebujących wsparcia i kształtowało się rozpoznanie rozmiarów niezbędnej, ogólnej pomocy. Wypada tu zaznaczyć, że z tej pomocy w 1940 r. korzystało już 1022390 osób. Faktyczne potrzeby były jednak znacznie większe ${ }^{37}$.

36 Ibidem, s. 67-72; por. także: M. Wrzosek, Wstęp do..., s. 2-3.

37 M. Wrzosek, Wstęp do..., s. 3. 
Najważniejszym źródłem środków przeznaczonych dla ludności nękanej coraz dotkliwszą niedolą, a nawet dotkliwą nędzą były początkowo dostawy docierające ze Stanów Zjednoczonych ${ }^{38}$. Do pierwszego spotkania przedstawicieli Niemieckiego Czerwonego Krzyża oraz osób występujących w imieniu RGO z reprezentantami Amerykańskiego Czerwonego Krzyża doszło w dniu 1 lutego 1940 r. Przybysze zza Oceanu uczestniczyli we wspólnej konferencji i wsłuchiwali się w treść odczytywanych memoriałów, które określały skalę i charakter rzeczywistych potrzeb. W 1940 r. nastąpiło jeszcze pięć podobnych spotkań. Podróżując po zabiedzonym kraju w towarzystwie przedstawicieli Niemieckiego Czerwonego Krzyża, delegaci amerykańscy starali się wnikać niekiedy w kwestie bardzo szczegółowe, ponieważ chodziło im o możliwie dokładne rozpoznanie potrzeb ludności polskiej39.

Dary amerykańskie napływały, jak już wiadomo, za pośrednictwem Niemieckiego Czerwonego Krzyża. Ich ilość, pomimo trudności transportowych i niechętnego stanowiska władz niemieckich, była bardzo pokaźna. Sprawy podziału napływających darów były rozwiązane w ten sposób, że Ukraińcom przyznawano $7 \%$ transportów, Żydom 17\%, zaś główna ich część, to znaczy $76 \%$ przypadała Polakom. W okresie następnym, to znaczy w $1941 \mathrm{r}$., gdy rozpoczęły się niemiecko-sowieckie działania wojenne, a obszar Generalnej Guberni nawiedziły różne żywiołowe klęski (wylewy rzek, gradobicia oraz pożary), nędza ludności pogłębiła się w sposób bardzo poważny i zaznaczył się kilkakrotny wzrost ilości podań o wsparcie. RGO usiłowała w miarę swoich możliwości sprostać oczekiwaniom potrzebu jących pomocy ${ }^{40}$. W tym samym czasie organizacja ta podlegała stopniowym, ale dość istotnym przeobrażeniom wewnętrznym.

$\mathrm{O}$ wewnętrznych zmianach organizacyjnych w RGO decydowały wprawdzie różnorodne okoliczności, ale największą rolę w tym zakresie odgrywało oddziaływanie władz niemieckich. W listopadzie 1941 r. Wydział Administracyjny Urzędu Generalnego Gubernatora uchylił autonomię polskich organizacji dobrowolnej opieki społecznej i zniósł ich statuty, a majątek, którym dysponowały obiecał przekazać RGO. Jednocześnie w drugim paragrafie statutu RGO nastąpiła zmiana uzasadniana przez władze niemieckie powołaniem Dystryktu Galicja na obszarze Wschodniej Małopolski i przyłaczeniem tej nowej jednostki administracyjnej do Generalnej Guberni. Sama zaś zmiana organizacyjna polegała na ograniczeniu reprezentacji Polaków

38 Sprawozdanie RGO za lata 1940-1941, s. 36.

39 M. Wrzosek, Wstęp do..., s. 3.

40 Ibidem. 
w centralnym organie RGO do liczby czterech osób i na powiększeniu przedstawicielstwa Ukraińców o jedną osobę. Nastąpiły też zmiany w kierownictwie biura wykonawczego RGO. Dotychczasowy dyrektor Witold Celichowski w lipcu 1941 r. został przeniesiony na stanowisko generalnego radcy prawnego Rady Opiekuńczej Miejskiej w Warszawie, a opuszczone przez niego stanowisko objął Edmund Seyfried (były dyrektor „Ruchu”, a wcześniej oficer II Oddziału w polskim Sztabie Generalnym ${ }^{41}$.

Pismem z 7 lipca $1941 \mathrm{r}$. władze niemieckie zmieniły także nazwę terenowych placówek RGO, określanych dotychczas jako miejskie lub powiatowe rady opiekuńcze i uznały, że są to komitety. Największa zmiana organizacyjna, jak już wiadomo, nastąpiła jednak wraz z powołaniem Dystryktu Galicja. Polskie komitety opieki społecznej zaczęły tam działać już w pierwszych tygodniach po opanowaniu tych obszarów przez wojska niemieckie. Powstawały jednak samorzutnie bądź też z inicjatywy niektórych przedstawicieli terenowych czynników administracyjnych nowego okupanta. Odbywało się to niezależnie od RGO, ale na zasadach wypracowanych już przez tę polską organizację charytatywną. Komitety opiekuńcze pojawiły się tam najwcześniej we Lwowie, a ich organizacją zajmował się mecenas doktor Leopold Tesznar. Jego działalność spotkała się z życzliwym wsparciem ze strony RGO, co znalazło swój wyraz podczas rychłej wizyty, jaką złożył tam dość wcześnie prezes Ronikier i towarzyszący mu dyrektor biura; był to zapewne już Edmund Seyfried. Osobom wizytującym nowy obszar chodziło o nawiązanie ściślejszej współpracy. Ostateczne zespolenie okręgu lwowskiego z głównym obszarem działalności RGO nastąpiło jednak dopiero w pierwszym kwartale $1942 \mathrm{r}$. W tym zaś okresie, który to zespolenie poprzedził, organizacja opiekuńcza Wschodniej Małopolski występowała jako Komitet Opiekuńczy we Lwowie. W swej ówczesnej działalności nie preferowała ona poczynań związanych $z$ organizacją wewnętrzną własnych struktur, lecz główne wysiłki koncentrowała na sprawach związanych $z$ bezpośrednią akcją opiekuńczą. Dopiero wówczas, gdy te najważniejsze sprawy w znacznym stopniu zostały już rozwiązane, rozpoczęła się rozbudowa własnych struktur organizacyjnych, reprezentowanych dotychczas przez tymczasowy sekretariat, który stał się „działem organizacy jnym”. Następnie została obmyślona trwalsza struktura organizacy jna wykonawczego biura lwowskiego Komitetu Opiekuńczego. Wiadomo, że jego działalność była koordynowana w sześciu wydziałach, ale ich nazw oraz dokładnego zakresu kompetencji nie udało się

41 Ibidem, s. 4; por. także: B. Kroll, op. cit., s. 75. 
ustalić $^{42}$. Szczegółowych informacji odnoszących się do tej kwestii nie ma również w opracowaniu Bogdana Krolla. Lwowskiemu komitetowi okręgowemu podlegały komitety powiatowe.

W 1942 r. nastąpiły dość istotne zmiany w strukturach centrali i w powiatowych komitetach RGO. W uzupełnionych sformułowaniach statutowych, narzuconych przez władze niemieckie, została utrzymana decyzja dotycząca rozwiązania wszystkich stowarzyszeń opiekuńczych, ale znikła wcześniejsza zapowiedź, z której wynikało, że mienie tych stowarzyszeń znajdzie się w dyspozycji RGO. W konsekwencji RGO została obarczona dodatkowymi ciężarami opiekuńczymi, a zasób środków, jakimi rozporządzała w toku swojej bezpośredniej działalności, nie powiększył się. Wprawdzie narzucone zmiany statutowe potwierdziły wcześniejszą decyzję władz niemieckich o likwidacji Żydowskiej Samopomocy Społecznej, ale dopływ zagranicznych darów był już w tym czasie bardzo skąpy, w istocie niemal równy zeru. W ten sposób zanikła potrzeba utrzymania Naczelnej Rady Opiekuńczej, która była dotychczas rzecznikiem potrzeb charytatywnych nie tylko Polaków, lecz także Żydów i Ukraińców ${ }^{43}$.

Bardzo poważną przeszkodę w działalności RGO stanowiły coraz liczniejsze aresztowania członków i pracowników tej organizacji charytatywnej. W czerwcu 1942 r. prezes RGO przedstawił generalnemu gubernatorowi listę, która obejmowała 209 nazwisk uwięzionych osób i podjął zabiegi o ich uwolnienie. Nadzieje związane $\mathrm{z}$ tymi zabiegami okazały się jednak płonne i do żadnych zwolnień nie doszło, ponieważ stanowisko władz niemieckich w tych sprawach było wyjątkowo nieustępliwe ${ }^{44}$.

$\mathrm{W}$ tym czasie nastąpiła jeszcze inna dość istotna zmiana $\mathrm{w}$ trybie działalności charytatywnej RGO. Polegała ona zaś na tym, że pod naciskiem władz niemieckich z tej działalności na dość długi okres musieli się wycofać przedstawiciele duchowieństwa rzymsko-katolickiego. Wywarło to bardzo niekorzystny wpływ na tok pomocy udzielanej przez RGO zwłaszcza na szczeblu powiatowym i gminnym. Na przełomie lat 1943 i 1944 władze niemieckie uznały, że decyzja dotycząca duchowieństwa nie była korzystnym posunięciem i złagodziły $\mathrm{w}$ tej sprawie swoje stanowisko.

Narastało również doświadczenie RGO i od 1942 r. najaktywniejsi działacze tej organizacji byli przeświadczeni, że najskuteczniejszym sposobem

42 M. Wrzosek, Wstęp do..., s. 4.

43 Por. ibidem, s. 13.

44 M. Wrzosek, Wstęp do..., s. 4. 
porozumiewania się koordynatorów akcji opiekuńczej z kierownikami terenowych placówek pomocy społecznej są bezpośrednie zjazdy. Do spotkań takich dochodziło zatem dość często, chociaż władze niemieckie okazywały organizatorom tych narad swoja wyraźną dezaprobatę. Zjazdy nie mogły jednak zastapić wszelkich kontaktów, jakich wymagała sprawna akcja opiekuńcza i wyłoniła się konieczność powołania tak zwanych referentów, którzy reprezentowali centralną instancję organizacji. Funkcjonując przy poszczególnych terenowych komitetach opiekuńczych, wizytowali oni wszystkie delegatury, docierając do nich w zasadzie raz na trzy lub cztery miesiące. Po każdym takim kontrolnym pobycie przedkładali swoje szczegółowe sprawozdania, które stanowiły potem przesłankę wydawanych zarządzeń i podejmowanych interwenc ji ${ }^{45}$.

Oprócz referentów organizacyjnych ożywioną akcję inspekcyjną podejmował także Wydział I Kontroli, którego pracownicy pojawiali się w terenowych delegaturach RGO bez zapowiedzi, a ponad to byli upoważnieni do sprawdzania działalności poszczególnych wydziałów samej centrali RGO. Działalność kontrolna podejmowała ponadto powoływana rokrocznie specjalna komisja obywatelska wyłaniana przez miarodajne środowiska społeczności polskiej. Najściślejszą kontrolę działalności RGO sprawowały jednak władze niemieckie, a w roli tego surowego kontrolera występował personel Wydziału Spraw Ludnościowych i Opieki Społecznej ustanowiony, jak wiadomo, w Urzędzie Generalnego Gubernatora. Istotny przejaw tego uciążliwego nadzoru stanowiła kontrola wszelkich pism wysyłanych przez centralę RGO. Wszystkie posiedzenia i narady członków centralnego organu RGO musiały się odbywać w obecności przedstawiciela władz niemiec$\mathrm{kich}^{46}$. Istotną rolę w kontaktach RGO z władzami niemieckimi odgrywały ponadto audiencje u samego generalnego gubernatora albo u podlegającego mu sekretarza stanu Josefa Bïhlera. W terenie kontakt między polskimi komitetami opiekuńczymi a niemieckimi władzami poszczególnych dystryktów podtrzymywali specjalni osobnicy, czyli tak zwani doradcy okręgowi. W roli czujnych kontrolerów występowali ponadto landraci ${ }^{47}$.

Tymczasem, liczba osób wspieranych materialnie przez RGO powiększała się ustawicznie i Rada była zmuszona nasilać swoją pomoc. Miała ona różnorodny charakter. Najwięcej środków wymagała akcja dożywiania

\footnotetext{
45 Ibidem.

46 Ibidem.

47 Ibidem, s. 5 .
} 
głodującej ludności. Zadanie to realizowała w stołówkach albo w kuchniach wydających obiady i suchy prowiant do domu. Szeroką akcję dożywiania rozwijały również szkoły wspomagane $z$ dotacji przyznawanych przez RGO. Największe trudności, jakie przezwyciężała RGO wyłaniały się natomiast przy udzielaniu podopiecznym pomocy odzieżowej. O trudnościach tych decydował dotkliwy niedobór źródeł zapewniających uzupełnianie szczupłych magazynów RGO. Rada usiłowała rozwiązywać ponadto mieszkaniowe potrzeby swoich podopiecznych. Istotną rolę odgrywały domy noclegowe i schroniska. Niektóre potrzeby były rozwiązywane dzięki pomyślnym, ale dość sporadycznym, wynikom poszukiwań podejmowanych przez pracowników tej opiekuńczej organizacji. Poważne znaczenie miała też pomoc opałowa polegająca na wydawaniu niewielkich ilości węgla kamiennego lub drewna. Jako uzupełnienie pomocy udzielanej w naturze występowało również wsparcie pieniężne, ale było ono stosowane przede wszystkim $w$ trzecim kwartale, gdy wyczerpywały się już zapasy magazynów RGO ${ }^{48}$.

Zasadniczymi formami opieki sanitarno-zdrowotnej zajmowały się natomiast organizacje samorządowe i Polski Czerwony Krzyż, ale nie odmawiała jej również RGO, ponieważ przekazywała zasiłki na zakup leków, na dożywianie chorych i finansowała działalność tak zwanych lotnych, czyli ruchomych szpitali epidemicznych. Realizowała ponadto przydział mydła i posiłkowała $\mathrm{w}$ ten sposób akcję sanitarną. Wyjątkową rolę odgrywała ponadto opieka specjalna polegająca na dostarczaniu pożywienia osobom uwięzionym, a także na udzielaniu zapomóg rodzinom uwięzionych. Akcja pomocy przeznaczonej dla więźniów oraz osób odjeżdżających na przymusowe roboty była przez Niemców widziana źle i niechętnie tolerowana. Miała jednak dość znaczne rozmiary. Stwierdzenie to dotyczy zwłaszcza opieki nad rodzinami uwięzionych.

Istotną rolę odgrywały ponadto takie poczynania RGO, które miały na celu materialne usamodzielnianie się podopiecznych. Cel ten był osiągany w ten sposób, że RGO pomagała różnym fachowcom przy zakładaniu przez nich własnych warsztatów pracy. Zasięg tych pożytecznych zabiegów nie był jednak znaczny, ponieważ Rada odczuwała najczęściej niedostatek zasobów finansowych. Duże powodzenie towarzyszyło natomiast poczynaniom związanym z zakładaniem należących do RGO tak zwanych warsztatów przemysłu domowego. Działalność ta przynosiła Radzie znaczne dochody i zapew- 
niała płatne zajęcie osobom w tych warsztatach zatrudnianym. Duże znaczenie miało także moralne wsparcie RGO, która podejmowała częste interwencje $\mathrm{w}$ sprawach związanych $\mathrm{z}$ aresztowaniem osób podejrzanych o niedopuszczalną działalność, albo w kwestiach dotyczących repatriacji osób zagrożonych przez ukraińskich nacjonalistów terrorem i masowymi morderstwami 49 .

O rozmiarach pomocy udzielanej przez RGO zbiedzonej ludności polskiej świadczą wyniki działalności, jaką ta organizacja podejmowała. Wiadomo mianowicie, że już w 1940 r. Rada udzieliła pomocy milionowej rzeszy podopiecznych W latach następnych rozmiary tej pomocy były jednak znacznie większe. Niezbędną pomoc otrzymywały osoby najbardziej takiego wsparcia potrzebujące. Nadużycia w tym zakresie nie były zjawiskiem częstym, ponieważ funkcjonowała skrupulatna kontrola zgłaszanych potrzeb. Istotną rolę w ocenie potrzeb odegrał między innymi fakt, że główną rolę w całej działalności RGO odgrywały osoby ofiarne, powodowane szlachetnymi pobudkami, osoby o nieposzlakowanej przeszłości. Wypada tu ponadto zaznaczyć, że na kierowniczych stanowiskach w tej niezwykle zasłużonej organizacji dominowały osoby arystokratycznego oraz inteligenckiego pochodzenia. Taka jest prawda, a stwierdzenie to ma swoje dobitne potwierdzenie $\mathrm{w}$ zachowanych aktach tej właśnie organizacji. Wypada ponadto stanowczo zaznaczyć, że w tych materiałach znajdują się także krytyczne informacje. Zawiera je, między innymi, sprawozdanie $z$ działalności podejmowanej przez RGO w 1942 r. W opracowaniu tym władze RGO przyznały samokrytycznie, że wystosowały do rolników kompromitujący apel o terminową realizację kontyngentów nakładanych przez niemieckie czynniki okupacyjne, co spotkało się z surową oceną ze strony miarodajnych środowisk polskiego społeczeństwa ${ }^{50}$.

Stosunki RGO z władzami niemieckimi układały się niezbyt pomyślnie, chociaż ta dobroczynna organizacja działała zgodnie $z$ zasadami opartymi na lojalności i ustępliwości utrzymywanej w granicach uzależnionych ogromnymi potrzebami pomocy społecznej, a zarazem dopuszczalnych polską racją stanu. Władze niemieckie w stosunkach z RGO okazywały natomiast twarde stanowisko podyktowane, jak to wynika $z$ powojennych dociekań historycznych, wrogimi wobec Polaków dalekosiężnymi zamysłami eksterminacyjnymi, a uzewnętrzniające się stosowaniem nie tylko metod uwzględniających daleko posuniętą dyskryminację ludności polskiej, ale

49 Ibidem.

50 Ibidem; por. także: Sprawozdanie Rady Gtównej Opiekuńczej za 1942 rok. 
także natężający się wciąż terror policyjny ${ }^{51}$. W początkowym okresie działalności RGO, a także w następnych kilkunastu miesiącach tego okresu, prezes Ronikier ulegał złudnym przeświadczeniom, że współistnienie między władzami niemieckimi a podlegająca mu polską organizacją charytatywną jakoś się unormuje i zacznie się układać w sposób możliwy do zniesienia.

O takich właśnie złudzeniach świadczyły tematy poruszane przez prezesa RGO oraz towarzyszących mu członków Rady podczas audiencji udzielanych im przez doktora Franka, a zwłaszcza memoriały kierowane przez prezesa RGO do generalnego gubernatora ${ }^{52}$. Przedstawiane memoriały nie przynosiły jednak oczekiwanych wyników, zaś reżim okupacyjny oparty na systemie policyjnego terroru potęgował próby zniewolenia polskich mieszkańców Generalnej Guberni, a w kierownictwie RGO utrzymywały się resztki złudnych oczekiwań na poprawę losów okupowanego obszaru. Te oczekiwania były podtrzymywane przenikającymi informacjami o sporach

51 O sprawach tych szeroko między innymi pisali: M. Broszat, Polityka narodowego socjalizmu w sprawie Polski. 1939-1945 (tłumaczenie), Warszawa-Poznań 1966, passim; Cz. Madajczyk, Generalna Gubernia w planach hitlerowskich, Warszawa 1961, passim; tegoż, Polityka III Rzeszy w okupowanej Polsce, Warszawa 1970, t. I-II, passim; L. Herzog, Na marginesie pracy Czestawa Madajczyka „Generalna Gubernia w planach hitlerowskich”, „Wojskowy Przegląd Historyczny” 1962, nr 4, passim; K. M. Pośpieszalski, Recenzja: Czestaw Madajczyk, Generalna Gubernia w planach hitlerowskich, Warszawa 1961, „Kwartalnik Historyczny”, t. LXIX, passim; J. Sehn, Hitlerowski plan walki biologicznej $z$ narodem polskim, „Biuletyn GKBZH w Polsce”, t. IV, 1948, passim; J. Gumkowski, K. Leszczyński, E. Rogoziński, Neuordnung Europas, w: Straty wojenne Polski w latach 1939-1945, Warszawa 1962; z publikacji tej wynika niezbicie, że władze hitlerowskich Niemiec już od końca 1940 r. dysponowały konkretnymi i dalekosiężnymi, ściśle tajnymi zamysłami dotyczącymi rozmiarów eksterminacji oraz przesiedlenia Polaków na bezkresne obszary Wschodu. Zamysły te były ujęte w dokumencie określonym jako „Generalplan Ost".

52 Serię memoriałów mających znaczenie zasadnicze zapoczątkował dokument sformułowany 27 października 1942 r. przez prezesa Ronikiera, który uskarżał się, że pomimo czerwcowych obietnic niemieckich nie ustał przymusowy wywóz Polaków na roboty do Rzeszy i nie nastąpiło wstrzymanie aresztowań, które nie omijały także pracowników RGO. Wywody Ronikiera znalazły dobitne wsparcie w memoriale skierowanym również do generalnego gubernatora przez arcybiskupa krakowskiego księcia Adama Sapiehy. W dokumencie tym, datowanym na 2 listopada 1942 r., a zawierającym odważne i ostro u jęte sformułowania, chodziło o obronę „,...] najwyższych wartości: godności ludzkiej i równowagi myśli [...]. To wszystko, co lud ten poniża, psuje, co mąci pojęcia o prawie, dobru i słuszności jest i musi być obce wszelkim poczynaniom władzy". W styczniu $1943 \mathrm{r}$. RGO przedłożyła generalnemu gubernatorowi dwa kolejne memoriały, występując przeciw wywozowi oraz metodom rekrutacji robotników do Rzeszy, a także przeciw wysiedleniom z Zamojszczyzny i upominała się o finansowe wsparcie pomocy udzielanej rodzinom osób wywiezionych na roboty. Sprawy te były następnie poruszane ponownie w memoriale z 29 maja 1943 r. 
dotyczących polityki stosowanej przez niemieckich okupantów na terenie Generalnej Guberni traktowanej jako swoista satrapia. Rozprzestrzeniały się mianowicie pogłoski, że doktor Frank jest zwolennikiem częściowego złagodzenia kursu postępowania na podlegającym mu obszarze okupacyjnym, ale natrafia na usilny sprzeciw czynników policyjnych i partyjnych III Rzeszy.

W decyzjach dotyczących tej sprawy uczestniczył nawet sam Hitler, reagując na memoriały nadsyłane do Berlina przez generalnego gubernatora; chodzi o pismo Hansa Franka do szefa Kancelarii Rzeszy (Reichkanzlei) Hansa Lammersa z 20 kwietnia 1943 r. oraz dokument przeznaczony bezpośrednio dla Hitlera z 19 czerwca tegoż roku. Führer podzielił stanowisko Franka, który opowiadał się za maksymalną eksploatacją i za priorytetowym pojmowaniem takich zamysłów, ale nie zgodził się na zastosowanie ułatwien, jakie w tym zakresie mogła przynieść łagodniejsza lub bardziej elastyczna polityka. W takiej oto sytuacji doktor Frank zrezygnował $\mathrm{z}$ własnych zamysłów i w swoim systemie władzy nawiązał do poprzedniego, ostrego kursu. Jego taktyczna innowacja, zgodnie $z$ sugestiami Heinricha Himmlera, polegała natomiast na bezwzględnym zwalczaniu i likwidowaniu Polaków uczestniczących w wystąpieniach przeciw III Rzeszy lub o takie wystąpienia podejrzanych ${ }^{53}$.

W odniesieniu do RGO zamysły generalnego gubernatora koncentrowały się natomiast na dążeniu do wykorzystania tej organizacji jako narzędzia propagandy władz niemieckich. Bardzo wyrazistą rolę propagandową miał odegrać między innymi udział członków RGO w uroczystej odprawie kolejnego transportu Polaków wywożonych na roboty do Rzeszy, a w wśród od jeżdżających znajdował się jakoby milionowy „ochotnik". Pomimo usilnego nacisku strony niemieckiej Rada nie wyraziła zgody na swoją oficjalną obecność w tej bezczelnej imprezie. Podczas tej imprezy, odbywającej się 13 marca 1943 r., na peronie krakowskiego dworca kolejowego pojawili się ostatecznie tylko dwaj członkowie władz RGO, to znaczy Edmund Seyfried i Władysław Wolter, ale zachowywali się biernie i, pomimo oczekiwania władz niemieckich, żadnych przemówień nie wygłaszali ${ }^{54}$.

Istotny wpływ na stanowisko Rady w tym czasie wywierały już te wydarzenia, które świadczyły dobitnie o zaostrzonym kursie polityki okupacyjnej w Generalnej Guberni. Jako jego znamienną zapowiedź wypada

53 O sprawach tych szeroko pisze Bogdan Kroll, op. cit., s. 286-289.

54 Ibidem, s. 282. 
uznać groźne ostrzeżenia przekazywane w Radomiu członkowi kierownictwa RGO Adamowi Walkowiakowi przez miejscowego radcę policji kryminalnej SS-Hauptsturmführera Paula Fuchsa. Podczas rozmowy, na która przedstawiciel strony polskiej został wezwany 9 sierpnia 1943 r., ten dość wysoki funkcjonariusz policji niemieckiej zapowiedział stosowanie zbiorowej odpowiedzialności $w$ razie ponownych zamachów na przedstawicieli władz niemieckich i w odpowiedzi na akty sabotażu. Ostrzeżenia takie Fuchs ponowił podczas kolejnej rozmowy, która odbyła się w dniu 27 sierpnia tegoż roku ${ }^{55}$. Te ostrzeżenia i następne, jeszcze groźniejsze zapowiedzi, jak się to później okazało, wywarły istotny wpływ na rezygnację prezesa Ronikiera z dotychczasowej, bardzo ostrożnej linii postępowania. Dalsze usztywnienie postawy prezesa RGO zaznaczyło się natomiast wówczas, gdy ostrzeżeniom Fuchsa zaczęło niebawem towarzyszyć srogie ich potwierdzenie.

W takiej oto sytuacji doszło do poważnego kryzysu w stosunkach między prezesem RGO a niemieckimi władzami Generalnej Guberni. Te okoliczności, które do kryzysu doprowadziły miały natomiast propagandowy charakter. Chodziło tym razem o obecność całego kierownictwa RGO w uroczystości dożynkowej, zapowiadanej w Krakowie już od lipca 1943 r., a przygotowywanej $z$ wielkim rozgłosem i rozmachem. Termin głównych uroczystości był zaś wyznaczony na dzień 24 października tegoż roku. Żądanie dotyczace udziału Rady w tej imprezie miało kategoryczny charakter i prezes Ronikier przygotował tekst swojego wystąpienia uzgadnianego mozolnie z przedstawicielem doktora Franka, to znaczy z Lotharem Weirauchem, kierownikiem Wydziału Spraw Ludności i Opieki w Urzędzie Generalnego Gubernatora. Tymczasem w ostatnich dniach przed zapowiadanymi dożynkami do prezesa RGO dotarły wiadomości o niemieckich przygotowaniach do masowych egzekucji odwetowych, które miały objąć Polaków skazanych przez sądy policyjne w Sanoku, Krakowie i Warszawie. Bogdan Kroll wzmiankuje w swojej monografii o odwołaniu egzekucji w Sanoku, dodając, że stało się to podobno w wyniku skutecznej interwencji Weiraucha ${ }^{56}$. Egzekucje w Krakowie i Warszawie zostały natomiast wykonane. Te tragiczne wydarzenia wywarły na Ronikierze tak głębokie wrażenie, że prezes RGO, działając w porozumieniu z całą Radą, wystosował 23 października 1943 r. do gubernatora Franka specjalne pismo, w którym oznajmił,

55 Ibidem, s. 331--340.

56 Ibidem, s. $314 \mathrm{i} \mathrm{n}$. 
że Rada nie weźmie udziału w uroczystości dożynkowej. Deklaracji tej prezes Ronikier nie cof nął pomimo zapowiedzi doktora Franka, że nastąpi rozwiązanie RGO. Postanowienie generalnego gubernatora o zawieszeniu tej organizacji w podejmowanej przez nią działalności ukazało się już 24 października, ale do realizacji tego postanowienia nie doszło. Generelny gubernator, działając za pośrednictwem Weiraucha, poprzestał ostatecznie na usunięciu z kierownictwa RGO prezesa Adama Ronikiera oraz profesora Władysława Woltera i Antoniego Starzeńskiego, dyrektora Seyfrieda poinformował o konieczności powołania innego prezesa, a potem wyraził zgodę na uzupełnienie uszczuplonego kierownictwa. Nowym prezesem RGO został przedwojenny sędzia Najwyższego Trybunału Administracyjnego Konstanty Tchórznicki ${ }^{57}$. W składzie osobowym organu, nad którym objął kierownictwo, oprócz dawnych jej członków znaleźli się Ludwik Dunin i Stanisław Wachowiak, który na posiedzenia dojeżdżał z Warszawy do Krakowa razem z Januszem Machnickim ${ }^{58}$.

Rada funkcjonująca w zmienionym składzie osobowym kontynuowała w zasadzie tę linię działalności, jakiej trzymał się poprzedni prezes, ale funkcjonowała w sposób znacznie ostrożniejszy, określany niekiedy nawet jako nazbyt bojaźliwy. Była zmuszona do przezwyciężania powiększających się nadal trudności, ponieważ możliwości opiekuńcze, jakimi dysponowała kurczyły się, a potrzeby wciąż narastały. Istotna zmiana $\mathrm{w}$ dziedzinie tych potrzeb zaczęła się uzewnętrzniać latem 1944 r. O zmianie tej zadecydował najpierw odwrót wojsk niemieckich, które były zmuszone ustąpić z obszarów Wschodniej Małopolski (Okręg Galicja - Dystrykt Galicjen), a potem $\mathrm{z}$ terenów położonych na wschód od środkowego biegu Wisły, gdzie zainstalowały się władze tak zwanego rządu lubelskiego i przejmując mienie RGO, przekazywały je komitetom opieki społecznej, powoływanym bez porozumienia $\mathrm{z}$ personelem terenowych komitetów opiekuńczych RGO59.

Wybuch Powstania Warszawskiego spowodował ponowny wzrost potrzeb opiekuńczych, co uwidoczniło się zwłaszcza po kapitulacji powstańczych sił zbrojnych i powszechnej ewakuacji mieszkańców lewobrzeżnych dzielnic niszczonej stolicy. W tym okresie kierownictwo RGO przebywało w Krakowie, a po części najpierw w Sochaczewie, a potem w Pruszkowie.

57 Ibidem, s. 317.

58 Ibidem, s. 443.

59 M. Wrzosek, Wstęp do..., s. 6. 
W odniesieniu do tego okresu działalności RGO są często podnoszone ciężkie zarzuty, że nie potrafiła zorganizować dostatecznej pomocy dla ogromnej rzeszy nowych podopiecznych. Przy ocenie tych zarzutów należy jednak pamiętać o bardzo ograniczonych możliwościach materialnych tej organizacji. Jej działalność zakończyła się na przełomie drugiej i trzeciej dekady stycznia, to znaczy w czasie styczniowej ofensywy wojsk sowieckich w $1945 \mathrm{r}$. W roli nowego opiekuna osób potrzebujących pomocy zaczął wtedy występować Centralny Komitet Opieki Społecznej. Był powołany przez władze Polski uzależnionej od Związku Radzieckiego. 